\title{
Infection with Hematodinium sp. in mud crabs Scylla serrata cultured in low salinity water in southern China
}

\author{
Yuan Y. Li ${ }^{1, *}$, Xiao A. Xia ${ }^{1}$, Qing Y. Wu1, Wen H. Liu, You S. Lin ${ }^{2}$ \\ ${ }^{1}$ Marine Biology Institute of Shantou University, Shantou, Guangdong 515063, PR China \\ ${ }^{2}$ Shantou Dashun Co. Limited, Shantou, Guangdong 515063, PR China
}

\begin{abstract}
Dinoflagellates in the genus Hematodinium are important parasites of wild marine crustaceans, but are rarely reported in waters with salinities $<11$ or from cultured crustaceans. Since 2005, the mud crab Scylla serrata, which is cultured along the coast of southeastern China, has suffered from an acute epizootic locally known as 'milky disease'. The disease mainly occurrs from September to November. The clinical signs are largely similar to those of crabs suffering from bitter crab disease (BCD) or pink crab disease (PCD), which are caused by parasites of the genus Hematodinium. To determine whether Hematodinium sp. is a pathogen of milky disease, histopathological examinations of mud crab haemolymph, hepatopancreas, heart and gill were conducted. In addition, previously reported Hematodinium molecular probes were applied to infected material. The results indicate that Hematodinium sp. is at least one of the main pathogens of milky disease. The salinity in $S$. serrata culture ponds was $<9$. To our knowledge, this is the first report showing the Hematodinium infection in a cultured crustacean in low salinity water.
\end{abstract}

KEY WORDS: Scylla serrata $\cdot$ Milky disease $\cdot$ Hematodinium sp. $\cdot$ Histopathology $\cdot$ Polymerase chain reaction $\cdot$ PCR

Resale or republication not permitted without written consent of the publisher

\section{INTRODUCTION}

Among dinoflagellates of the genus Hematodinium are important parasites of wild marine crustaceans (Stentiford \& Shields 2005). However, due to the lack of distinctive characteristics and the poorly understood life history of the species in this genus, only 2 have been morphologically described. One is $H$. perezi, which was first described from the portunid crabs Liocarcinus depurator and Carcinus maenas along the French coast (Chatton \& Poisson, 1931). A second species, H. australis, was described from the sand crab Portunus pelagicus in Australia (Hudson \& Shields 1994).

Hematodinium is systemically distributed in infected crustaceans. Infection by the disease produces a series of observable negative effects, such as an opaquely discolored carapace, unpalatable flavor, change of meat appearance, and high mortality. These observations strongly suggest a large economic loss to the commercial fishery (Meyers et al. 1987, Taylor \& Khan 1995). The nature and extent of Hematodinium epizootics can be affected by host size and sex, seasonality, and environmental factors such as ambient salinity (Stentiford \& Shields 2005). Available data indicate that Hematodinium infections rarely occur below a salinity of 11 (Newman \& Johnson 1975, Messick \& Sinderman 1992, Messick \& Shields 2000) or in cultured crabs.

The mud crab Scylla serrata is one of the most valuable shellfish species and the largest crab fishery in China. It is widely cultured in brackish and seawater ponds along the coast of southeastern China. In 2004, the total culture area was about 35000 ha, and the yield was around 10000 t. The city of Shantou in Guangdong province, southern China, is one of the main mud crab culture areas with about 7000 ha. Since 2005, cultured mud crabs in this area have suffered from an epizootic locally known as 'milky disease'. The salinity in the mud crab culture ponds is $<9$ throughout 
the year. The disease breaks out mainly in the fall, from September to November, when the crab is near maturity, and the high mortality (usually $>60 \%$ ) has resulted in large economic losses. Clinical signs of the disease are largely similar to those in Chinoecetes bairdi, Cancer pagurus and C. opilio suffering from a disease named bitter crab disease (BCD) or pink crab disease (PCD), which is caused by parasitic dinoflagellates of the genus Hematodinium (Meyers et al. 1987, Taylor \& Khan 1995, Stentiford et al. 2002). Despite the low salinity in the culture ponds, Hematodinium has been the suspected pathological agent based on the presence of milky crab hemolymph. As a result, histopathological examinations of crab haemolymph, hepatopancreas, heart and gill were conducted. In addition, Hematodinium-specific gene primers were applied. Diagnosis and potential treatment of the disease is critical for disease control, which will enhance development of the Scylla serrata fishery.

\section{MATERIALS AND METHODS}

Sampling and histopathological observation. From September to November 2006 and 2007, a total of 12 batches including 48 healthy and 121 diseased Scylla serrata individuals were collected from the 2000 ha Niutianyang culture area in Shantou, Guangdong province, southern China. Upon their arrival at the laboratory, size, weight, sex and any clinical signs were recorded.

After the crabs were anaesthetised by chilling on ice, haemolymph was collected at the axillae of the 5th swimmer leg with a $1.0 \mathrm{ml}$ syringe, and 2 kinds of smears were prepared for each crab. One was immediately examined under a light microscope. The other was stained with hematoxylin and eosin (H \& E) after fixation with Bouin's solution, or without fixation.

Tissues of hepatopancreas, heart and gill were fixed in Bouin's solution $\left(4^{\circ} \mathrm{C}\right)$ for 12 to $24 \mathrm{~h}$, dehydrated in a graded ethanol series and embedded in paraffin. Sections ( 4 to $6 \mu \mathrm{m}$ thick) were excised and stained with $\mathrm{H} \& \mathrm{E}$, examined under a light microscope (Zeiss Axioplan 2), and representative digital images were captured.

Salinities in the crab culture area were monitored at 6 locations from April to December 2007 with a DREL 2800 (Hach) water quality analysis system. Salinity ranged from $4.41 \pm 0.17$ (mean $\pm \mathrm{SE}$ ) to $8.24 \pm 0.28$ $(\mathrm{n}=6)$ throughout the year (Fig. 1).

Molecular identification of Hematodinium. Genomic DNA was extracted from haemolymph, hepatopancreas and chela muscles, and purified with the Protocol-BS473 Classic Genomic DNA Isolation Kit (Bio Basic) as described by Stentiford et al. (2002). DNA concentrations were measured with a UV-2501 PC

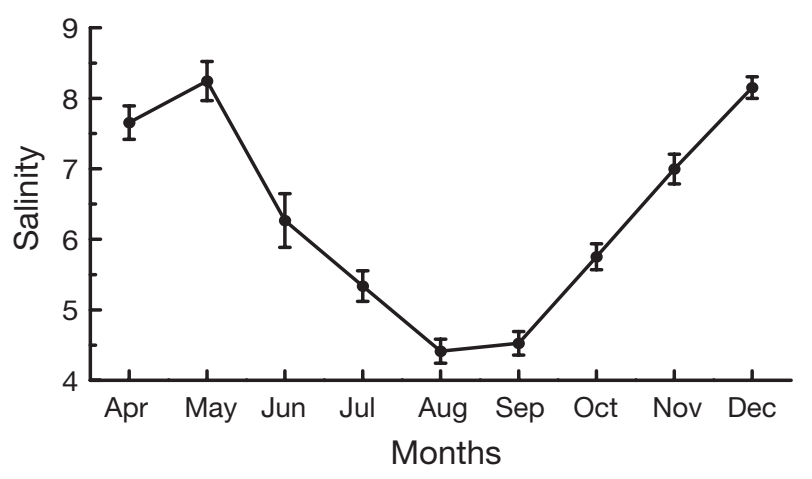

Fig. 1. Scylla serrata infected with Hematodinium-like parasites. Monthly salinity changes in culture ponds. Means \pm SE $(n=6)$

spectrophotometer (Shimadzu) and the values were 0.11 to $0.13 \mu \mathrm{g} \mathrm{\mu l} \mathrm{l}^{-1}$.

Using the isolated DNA as template, a polymerase chain reaction (PCR) was conducted with reported Hematodinium primers (Hemat-F-1487 and Hemat-R1654) as described by Gruebl et al. (2002). Primer concentration was $10 \mu \mathrm{M}$. PCR reactions were started with an initial denaturation at $94^{\circ} \mathrm{C}$ for $5 \mathrm{~min}$, followed by 40 cycles at $94^{\circ} \mathrm{C}$ for $30 \mathrm{~s}, 56^{\circ} \mathrm{C}$ for $30 \mathrm{~s}$ and $72^{\circ} \mathrm{C}$ for $45 \mathrm{~s}$, and with a final extension step at $72^{\circ} \mathrm{C}$ for $10 \mathrm{~min}$ in a total volume of $25 \mu \mathrm{l}$ containing $1 \mu \mathrm{l}$ of each primer, $2 \mu \mathrm{l}$ of template $(0.22$ to $0.26 \mu \mathrm{g})$ and $12.5 \mu \mathrm{l}$ PCR MasterMix (TianGen). The PCR products were separated by electrophoresis on a $1.5 \%$ ethidium bromide-stained agarose gel and viewed under a UV light source. The expected length of the PCR product was $187 \mathrm{bp}$ (Gruebl et al., 2002). Crabs ( $\mathrm{n}=5$ to 8 ) were examined for each tissue.

\section{RESULTS}

\section{Clinical signs}

Scylla serrata suffering from severe milky disease exhibited some gross symptoms such as moribund behavior, death shortly after capture or during transit, a cooked appearance and milky body fluid. The haemolymph lacked clotting ability and chela muscle became liquified. These clinical signs were largely similar to those of crabs suffering from BCD or PCD caused by Hematodinium infection (Meyers et al. 1987, Taylor \& Khan 1995, Stentiford et al. 2002).

\section{Histopathological changes}

In heavily infected individuals, the hemocyte count in haemolymph decreased sharply. Under light micro- 
scopy, parasites of various shapes or putative developmental stages were observed in fresh hemolymph smears. Parasites were observed as single round cells, sporonts, dinospores or round trophonts with many refractile granules (Fig. 2a-d), as observed in Callinectes sapidus (Shields \& Squyars 2000, Stentiford \& Shields 2005). In addition, we found uninucleate (Fig. 2e) and multinucleate or dividing parasites (Fig. 2f) as observed in Hematodinium-infected C. sapidus (Messick 1994).

The hepatopancreas of healthy crabs possessed robust hepatopancreatic tubules as demonstrated by the presence of active R- and B-cells (Johnson 1980) and spongy connective tissues between tubules
(Fig. 3a). In advanced milky disease crabs, spongy connective tissues were greatly diminished and became obscured by the proliferating parasite. The epithelium of hepatopancreatic tubules became atrophied, revealing a dilated lumen (Fig. 3b). In contrast to the hearts of healthy crabs (Fig. 3c), numerous parasites were observed in those of heavily infected individuals. The myocardium of heavily infected crabs underwent coagulative necrosis (Fig. 3d). The gill structure of healthy crabs appeared as described by Johnson (1980) (Fig. 3e). In heavily diseased crabs, the respiratory epithelia were greatly diminished as the lamellae became engorged by the proliferating parasite (Fig. 3f).
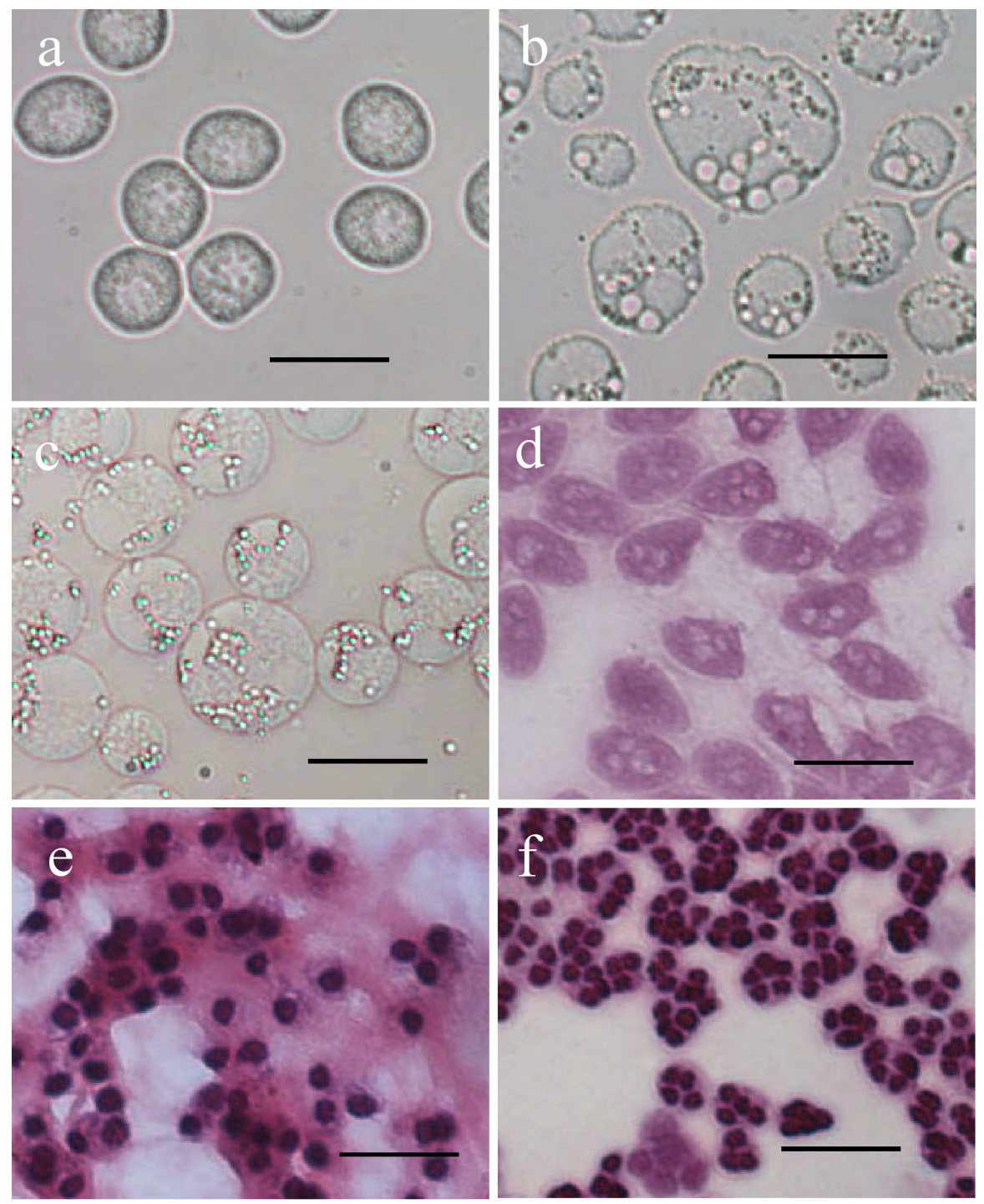

Fig. 2. Scylla serrata infected with Hematodinium-like parasites. Light micrographs of haemolymph from heavily infected mud crabs showing different shapes or developmental stages of the parasites. (a) Round cells; (b) sporonts; (c) round trophonts with many refractile granules; (d) dinospores; (e) uninucleate parasites; (f) multinucleate or dividing parasites. (a-c) Direct observation of fresh smears; (d) smear stained with hematoxylin and eosin without fixation; (e, f) smears stained with hematoxylin and eosin after fixation with Bouin's solution. Scale bars $=20 \mu \mathrm{m}$ 

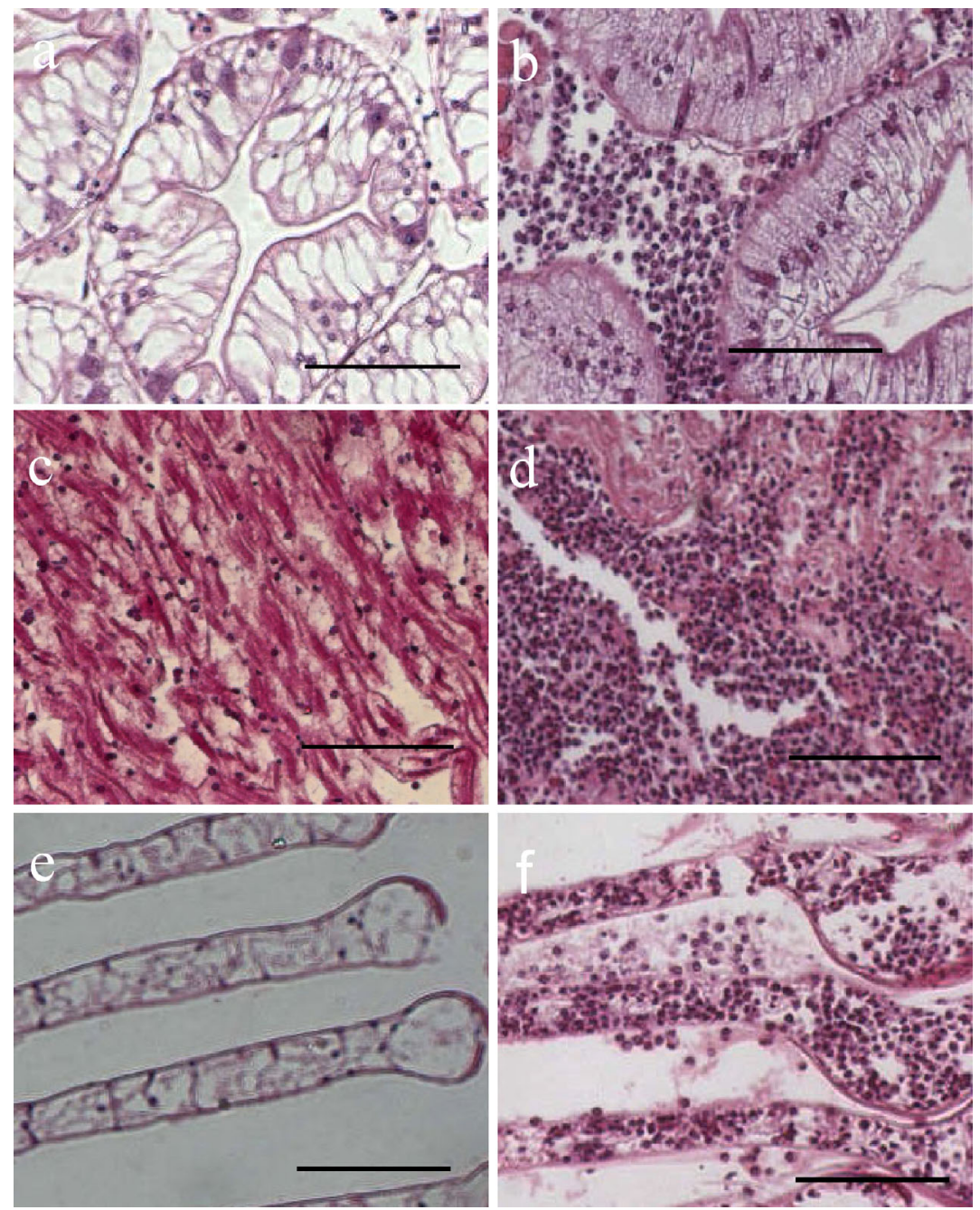

Fig. 3. Scylla serrata. Light micrographs of $(\mathrm{a}, \mathrm{b})$ hepatopancreas, $(\mathrm{c}, \mathrm{d})$ heart, and $(\mathrm{e}, \mathrm{f})$ gill. Compared with the tissue structure of healthy crabs $(\mathrm{a}, \mathrm{c}, \mathrm{e})$, tissue from heavily infected individuals $(\mathrm{b}, \mathrm{d}, \mathrm{f})$ is severely damaged and filled with Hematodiniumlike parasites. Scale bars $=100 \mu \mathrm{m}$

\section{Molecular evidence of Hematodinium in milky diseased crabs}

In the PCR amplification with reported Hematodinium primers (Gruebl et al. 2002), an expected band of about $187 \mathrm{bp}$ was obtained from all the genomic DNA samples of hepatopancreas, muscle and haemolymph of Scylla serrata with milky disease. While diagnostic bands were absent from hepatopancreas of healthy individuals (Fig. 4).

\section{DISCUSSION}

Parasitic dinoflagellates in the genus Hematodinium have gained attention as pathogens of commercially important crustaceans. Infections have been described from several wild marine crustacean hosts in Europe, USA and Australia (see 'Introduction'), but have seldom been reported in cultured crustaceans. Recently, Hematodinium infections have been reported in cul-

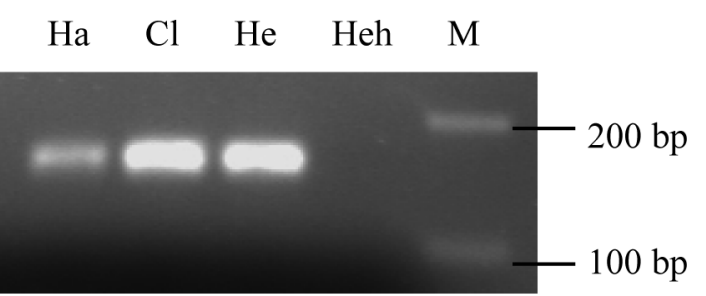

Fig. 4. Hematodinium-like diagnostic bands detected by PCR in haemolymph (Ha), claw muscle $(\mathrm{Cl})$ and hepatopancreas (He) from infected mud crab Scylla serrata. Diagnostic bands for the parasite are not in hepatopancreas (Heh) from a healthy individual. M: DNA marker 
tured Portunus trituberculatus (Xu et al. 2006, 2007b) and Scylla serrata (Xu et al. 2007a) in eastern China. The present study showed that the clinical signs and histopathological changes in haemolymph, hepatopancreas, heart and gill in $S$. serrata with milky disease were similar not only to those observed in crustaceans suffering from BCD or PCD, which were infected by Hematodinium (Meyers et al. 1987, Taylor \& Khan 1995, Stentiford et al. 2002), but also to those in P. trituberculatus and $S$. serrata (Xu et al. 2006, 2007a,b). The results suggest that Hematodinium sp. is at least one of the main pathogens of milky disease. This was further supported at the molecular level by the expected amplification of the PCR band with the Hematodinium primer set (Gruebl et al. 2002) in the tissues of diseased crabs but not in healthy individuals (Fig. 4). Comparing the reports of $\mathrm{Xu}$ et al $(2006,2007 \mathrm{a}, \mathrm{b})$ with results of the present study, it is apparent that the Hematodinium infection synchronously broke out in cultured crabs grown in both eastern and southern China. These are the first reports of a Hematodinium infection in crustaceans in China.

Several factors, including host factors (size or maturity status, age, sex, moult condition), seasonality and environmental factors (temperature, salinity), may affect the epidemiology of Hematodinium (Stentiford \& Shields 2005). What should be noted is that the available data show Hematodinium to be most prevalent in crabs from high salinity waters (Messick \& Shields 2000, Stentiford \& Shields 2005, Xu et al. 2006, $2007 \mathrm{a}, \mathrm{b}$ ); it is rarely reported below 11 salinity (Newman \& Johnson 1975, Messick \& Sinderman 1992, Messick \& Shields 2000). In the present study, however, Hematodinium-infection broke out in Scylla serrata cultured at salinities below 9. The characteristics of the parasite and the infection mechanism need to be further clarified.

The natural or in vivo life cycle of Hematodinium parasites is not fully understood. However, the parasite (isolated from Nephrops norvegicus) has been grown in culture (Appleton \& Vickerman 1998), and partial life cycles of parasitic dinoflagellates from the host species Chionoecetes bairdi and C. sapidus are known (Meyers et al. 1987, Shields \& Squyars 2000). Furthermore, different life cycle stages of Hematodinium parasites from C. sapidus, C. opilio and N. norvegicus have been reported (Messick 1994, Taylor \& Khan 1995, Appleton \& Vickerman 1998, Shields \& Squyars 2000, Stentiford \& Shields 2005). In this study, different developmental stages of parasites were observed in the haemolymph smears while only one type of parasite was found in histological sections of Scylla serrata with milky disease. Similar results have also been reported in other Hematodinium-infected crustaceans, which suggests that future studies need to resolve the differences between life history stages of in vitro cultures or in haemolymph and those observed in histological sections (Stentiford \& Shields 2005).

The present study revealed severe histopathological changes in the hepatopancreas, gills and heart of Scylla serrata with milky disease, similar to reports from some other Hematodinium-infected crustaceans (Meyers et al. 1987, Field et al. 1992, Hudson \& Shields 1994, Messick 1994, Stentiford et al. 2002, Sheppard et al. 2003, Wheeler et al. 2007). In Hematodinium infections, parasitic congestion and disruption of the gills, heart and other tissues lead to respiratory dysfunction or decrease of metabolic function and finally to host death. This may account for the high mortality of mud crabs with milky disease.

A range of methods, such as the observation of clinical signs, microscopic examination, indirect immunofluorescent antibody technique (IFAT), PCR- and ELISA-based diagnostic methods have been developed for the detection and assessment of Hematodinium infections in crustaceans. An external assessment of the opaquely discolored carapace proved to be a simple and rapid field diagnostic tool for Hematodinium infection of heavily infected Scylla serrata, but was not useful for detecting low-level infections, as reported for some other crabs (Meyers et al. 1987, Field et al. 1992, Shields \& Squyars 2000, Stentiford et al. 2001, 2002, Pestal et al. 2003). Microscopic determination of haemolymph smears is a reliable, cost-effective and permanent method for the diagnosis of Hematodinium infection in crabs (Stentiford \& Shields, 2005). Similarly, histopathological examination and PCRbased molecular diagnostic techniques are applicable to Hematodinium infection in $S$. serrata as in other crabs (Field et al. 1992, 1998, Field \& Appleton 1995, Dawe 2002, Gruebl et al. 2002, Stentiford et al. 2002, Pestal et al. 2003, Sheppard et al. 2003, Shields et al. 2005).

Acknowledgements. This work was financially supported by grants from the Science and Technology Project of Guangdong Province (No. 2007B090400049, 2006A36502004 \& 2008B020800004) and the National Natural Science Foundation of China (No. 30671629 \& 30570325 ) to Y.Y.L.

\section{LITERATURE CITED}

Appleton PL, Vickerman K (1998) In vitro cultivation and development cycle in culture of a parasitic dinoflagellate (Hematodinium sp.) associated with mortality of the Norway lobster (Nephrops norvegicus) in British waters. Parasitology 116:115-130

Chatton E, Poisson R (1931) Sur l'existence, dans le sang des crabs, de peridiniens parasites: Hematodinium perezi n.g., n.sp. (Syndinidae). CR Seances Soc Biol Paris 105:553-557

Dawe E (2002) Trends in the prevalence of bitter crab disease caused by Hematodinium sp. in snow crab (Chionoecetes 
opilio) throughout the Newfoundland and Labrador continental shelf. In: Paul AJ, Dawe EG, Elner R, Jamieson GS and others (eds) Crabs in cold water regions: biology, management, and economics. Alaska Sea Grant Report AK-SG-02-01, Alaska Sea Grant Program, University of Alaska, Fairbanks, AK, p 385-400

Field RH, Appleton PL (1995) A Hematodinium-like dinoflagellate infection of the Norway lobster Nephrops norvegicus: observations on pathology and progression of infection. Dis Aquat Org 22:115-128

Field RH, Chapman CJ, Taylor AC, Neil DM, Vickerman K (1992) Infection of the Norway lobster Nephrops norvegicus by a Hematodinium-like species of dinoflagellate on the west coast of Scotland. Dis Aquat Org 13:1-15

Field RH, Hills JM, Atkinson RJA, Magill S, Shanks AM (1998) Distribution and seasonal prevalence of Hematodinium sp. infection of the Norway lobster (Nephrops norvegicus) around the west coast of Scotland. ICES J Mar Sci 55:846-858

Gruebl T, Frischer ME, Sheppard M, Neumann M, Maurer AN, Lee RF (2002) Development of an 18S rRNA gene targeted PCR based diagnostic for the blue crab parasite Hematodinium sp. Dis Aquat Org 49:61-70

Hudson DA, Shields JD (1994) Hematodinium australis n. sp., a parasitic dinoflagellate of the sand crab Portunus pelagicus from Moreton Bay, Australia. Dis Aquat Org 19: 109-119

Johnson PT (1980) Histology of the blue crab, Callinectes sapidus: course of infection and histopathology. Praeger Publishers, New York

> Messick GA (1994) Hematodinium perezi infections in adult and juvenile blue crabs Callinectes sapidus from coastal bays of Maryland and Virginia, USA. Dis Aquat Org 19: 77-82

Messick GA, Shields JD (2000) Epizootiology of the parasitic dinoflagellate Hematodinium sp. in the American blue crab Callinectes sapidus. Dis Aquat Org 43:139-152

Messick GA, Sinderman CJ (1992) Synopsis of principal diseases of the blue crab, Callinectes sapidus. US Department of Commerce, NOAA Tech. Memo. NMFS-F/ NEC 88

Meyers TR, Koeneman TM, Bothelho C, Short S (1987) Bitter crab disease: a fatal dinoflagellate infection and marketing problem for Alaskan Tanner crabs Chionoecetes bairdi. Dis Aquat Org 3:195-216

Newman MW, Johnson CA (1975) A disease of blue crabs (Callinectes sapidus) caused by a parasitic dinoflagellate, Hematodinium sp. J Parasitol 61:554-557

Pestal GP, Taylor DM, Hoenig JM, Shields JD, Pickavance R (2003) Monitoring the presence of the lethal parasite

Editorial responsibility: Grant Stentiford,

Weymouth, UK
Hematodinium sp. in snow crabs from Newfoundland. Dis Aquat Org 53:67-75

Sheppard M, Walker A, Frischer ME, Lee RF (2003) Histopathology and prevalence of the parasitic dinoflagellate Hematodinium sp., in crabs (Callinectes sapidus, Callinectes similis, Neopanope sayi, Libinia emarginata, Menippe mercenaria) from a Georgia estuary. J Shellfish Res 22:873-880

Shields JD, Squyars CM (2000) Mortality and hematology of blue crabs, Callinectes sapidus, experimentally infected with the parasitic dinoflagellate Hematodinium perezi. Fish Bull 98:139-152

Shields JD, Taylor DM, Sutton SG, O'Keefe PO, Collins PW, Ings DW, Pardy AL (2005) Epizootiology of bitter crab disease (Hematodinium sp.) in snow crabs, Chionoecetes opilio, from Newfoundland, Canada. Dis Aquat Org 64: $253-264$

Stentiford GD, Shields JD (2005) A review of the parasitic dinoflagellates Hematodinium species and Hematodinium-like infections in marine crustaceans. Dis Aquat Org 66:47-70

Stentiford GD, Neil DM, Atkinson RJA (2001) The relationship of Hematodinium infection prevalence in a Scottish Nephrops norvegicus population to seasonality, moulting and sex. ICES J Mar Sci 58:814-823

Stentiford GD, Green M, Bateman K, Small HJ, Neil DM, Feist SW (2002) Infection by a Hematodinium-like parasitic dinoflagellate causes Pink Crab Disease (PCD) in the edible crab Cancer pagurus. J Invertebr Pathol 79: 179-191

Taylor DM, Khan RA (1995) Observations on the occurrence of Hematodinium sp. (Dinoflagellata: Syndinidae): the causative agent of Bitter Crab Disease in the Newfoundland snow crab (Chionoecetes opilio). J Invertebr Pathol 65:283-288

- Wheeler K, Shields JD, Taylor DM (2007) Pathology of Hematodinium infections in snow crabs (Chionoecetes opilio) from Newfoundland, Canada. J Invertebr Pathol 95: 93-100

Xu WJ, Xu HX, Shi H (2006) Diagnoses of Hematodinium of Portunus trituberculatus (Miers) and countermeasure for comprehensive prevention and treatment. Mod Fish Info $21: 27-28$

Xu WJ, Sheng XZ, Xu HX, Shi H, Li PF (2007a) Dinoflagellates Hematodinium sp parasitizing the mud crab Scylla serrata. Period Ocean Univ China 37:916-920 (in Chinese with English abstract)

Xu WJ, Shi H, Xu HX, Hamish S (2007b) Preliminary study on the Hematodinium infection in cultured Portunus trituberculatu. Acta Hydrobiol Sini 31:637-642

Submitted: July 14, 2008; Accepted: September 19, 2008

Proofs received from author(s): October 31, 2008 